\title{
Experiences, dietary behavior and cultural characteristics of people with colorectal neoplasms
}

\author{
Experiências, comportamento alimentar e características culturais de pessoas com neoplasias colorretais \\ Experiencias, conducta alimentaria y características culturales de personas con neoplasias colorrectales
}

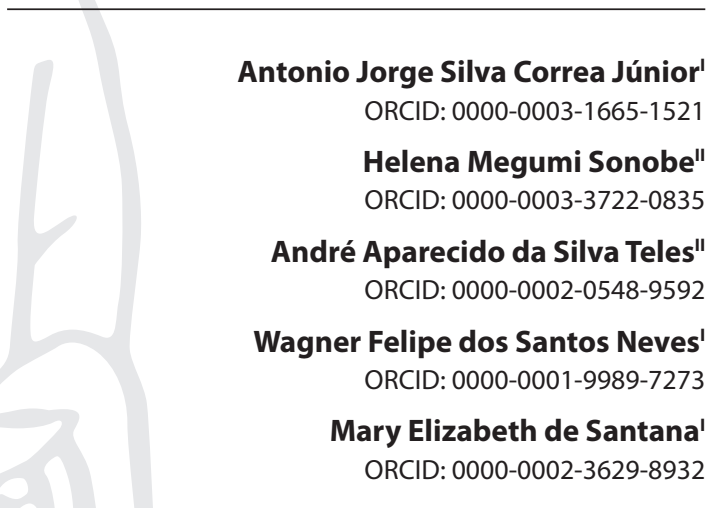

'Universidade Federal do Pará. Belém, Pará, Brazil. "Universidade de São Paulo. Ribeirão Preto, São Paulo, Brazil.

How to cite this article: Correa Júnior AJS, Sonobe HM, Teles AAS, Neves WFS, Santana ME. Experiences, dietary behavior and cultural characteristics of people with colorectal neoplasms. Rev Bras Enferm. 2021;74(1):e20200092. doi: http://dx.doi.org/10.1590/0034-7167-2020-0092

\section{Corresponding author:}

Antonio Jorge Silva Correa Júnior E-mail: juniorjorge_94@hotmail.com

EDITOR IN CHIEF: Antonio José de Almeida Filho ASSOCIATE EDITOR: Fátima Helena Espírito Santo

Submission: $04-08-2020$

Approval: 09-15-2020

\section{ABSTRACT}

Objectives: to interpret the socio-cultural, religious, and spiritual aspects of the experience of people who have colorectal cancer and were submitted to surgical treatment with ostomy. Methods: ethnographic study under the perspective of the Sociology of Health, in the comprehensive aspect, in a surgical unit of an oncologic hospital of the state of Pará, Brazil. Eighteen deponents participated, eleven patients, and seven caregivers, between December 2018 and March 2019. Data were obtained with non-participant observation, field diary records, and semi-structured interviews with subsequent inductive content analysis. Results: religious attachment and socio-cultural aspects of the illness were interpreted, emphasizing the social fact of the Immediate Dream, emotional shock, modern totemism, toxic food as taboo, and medicalization in the sphere of common sense and biomedical system. Final Considerations: microsocial and macrosocial factors of the participants' experiences contribute to the qualification of oncologic assistance in the public system, assuming the need for specialized interprofessional assistance.

Descriptors: Colorectal Neoplasms; Oncologic Nursing; Dietary Behavior; Cultural Characteristics; Medical Sociology

\section{RESUMO}

Objetivos: interpretar os aspectos socioculturais, religiosos e espirituais da experiência de adoecimento de pessoas por câncer colorretal submetidas ao tratamento cirúrgico com estomização. Métodos: estudo etnográfico sob a perspectiva da Sociologia da Saúde, na vertente compreensiva, em unidade cirúrgica de um hospital oncológico do estado do Pará, Brasil. Participaram 18 depoentes, sendo 11 adoecidos e 7 cuidadores, entre dezembro de 2018 e março de 2019. Os dados foram obtidos com observação não participante/participante, registro em diário de campo e entrevista semiestruturada com posterior análise de conteúdo indutiva. Resultados: interpretaramse o apego religioso e aspectos socioculturais do adoecimento, enfatizando o fato social do Sonho Imediato, choque emocional, totemismo moderno, reimosidade alimentar como tabu e a medicalização na esfera do senso comum e sistema biomédico. Considerações Finais: fatores microssociais e macrossociais das experiências dos participantes contribuem na qualificação da assistência oncológica no sistema público, pressupondo a necessidade de uma assistência interprofissional especializada. Descritores: Neoplasias Colorretais; Enfermagem Oncológica; Comportamento Alimentar; Características Culturais; Sociologia Médica.

\section{RESUMEN}

Objetivos: interpretar aspectos socioculturales, religiosos y espirituales de experiencia de enfermedad de personas por cáncer colorrectal sometidas al tratamiento quirúrgico con estomatización. Métodos: estudio etnográfico bajo la perspectiva de la Sociología de Salud, en la vertiente comprensiva, en unidad quirúrgica de un hospital oncológico de Pará, Brasil. Participaron 18 deponentes, siendo 11 enfermos y 7 cuidadores, entre diciembre de 2018 y marzo de 2019. Los datos obtenidos con observación no participante/participante, registro en diario de campo y entrevista semiestructurada con posterior análisis de contenido inductivo. Resultados: interpretaron el apego religioso y aspectos socioculturales del enfermo, enfatizando el hecho social del Sueño Inmediato, choque emocional, totemismo moderno, la reimosidad alimentaria como tabú y la medicalización en la esfera del sentido común y sistema biomédico. Consideraciones Finales: factores microsociales y macrosociales de las experiencias de los participantes contribuyen en cualificación de asistencia oncológica en el sistema público, presuponiendo la necesidad de una asistencia interprofesional especializada. Descriptores: Neoplasias Colorrectales; Enfermería Oncológica; Conducta Alimentaria; Características Culturales; Sociología Médica. 


\section{INTRODUCTION}

The disease of colorectal cancer (CRC) and the possibility of ostomy have an impact on social life. In general, health care is limited to the disease and does not encompass the totality experienced regarding the impending critical condition and existential coherence ${ }^{(1)}$. This differs from the perspective of the patient, who has a system of beliefs, knowledge, and expectations during the itinerary in the Unified Health System (SUS) - the latter having a biomedical hegemonic model.

In Brazil, for each year of the triennium 2020-2022, it has been estimated 20.520 cases of colon and rectum cancer in males and 20.470 in females, and in the state of Pará, Brazil, 200 new cases will be diagnosed in males and 270 in females, totaling 470 new cases each year ${ }^{(2)}$. The severity is categorized into four stages by the Union for International Cancer Control (UICC), ranging from "localized to colon lining" (stage 1) to "spread to other organs" (stage 4 or metastatic disease) ${ }^{(3)}$.

Thus, surgery with the confection of a stoma, i.e., the exteriorization of the ileum (ileostomy) or colon (colostomy) through the abdominal wall for intestinal elimination constitutes the predominant treatment for the CRC. The process of illness and subsequent ostomization generates physiological repercussions such as the release of gases and unpleasant noises, in addition to fatigue, culminating in psychosocial repercussions such as depression and dissatisfaction with the appearance through the use of collecting equipment ${ }^{(4)}$.

In this sense, the nursing action is to be aware of the psychoemotional needs guiding the relatives about the treatment and life after ostomy ${ }^{(3)}$. In nursing care planning, it must be included the microsocial and macrosocial factors involved in the illness and the context of care. The microsocial factors are linked to the interactions of professionals with the patients, face-to-face behavior, and the perioperative care in the institutions, acting on the experience and repercussions in those patients and their families' lives, who depend on the SUS macrosocial factors ${ }^{(5-6)}$. Therefore, in this ethnographic study, it was chosen the theoretical reference of Sociology of Health.

This theoretical line, initially called Medical Sociology, analyzes and interprets the social fact as the totality of ways of thinking, acting, and feeling, which are external to the patient and constructed in the collective habit (of cultural, juridical, or moral origin), influencing individual experiences ${ }^{(7)}$. Some themes have been studied with this perspective, such as stigma, social identity, deviation, behavior in the disease, autonomy, medicalization, and lay experience ${ }^{(8)}$. With a focus on nursing, phenomenological and comprehensive sociologies have sought to deepen the biographical situation, social relations, past and present experiences ${ }^{(9)}$, social practice, macro social and microsocial contexts ${ }^{(10)}$, body, social being, joint experiences, stigma, and spirituality ${ }^{(11)}$, through dense data.

In turn, the ethnographic method apprehends the experience by analyzing the beliefs, behaviors, and interactions with the researcher's coexistence in a specific context. In the case of CRC in the anthropological and socio-historical aspect, it is highlighted an English field research with 39 patients, reporting that inadequate professional support led to confusion and despair ${ }^{(12)}$. Therefore, it is pressing to highlight the socio-cultural, religious, and spiritual factors inherent to the dynamics of the life of these patients, which occur in the experience of hospitalization in the Brazilian Health System and whose understanding would contribute to the improvement of humanization.

Investigating CRC disease using the support of Sociology of Health enables nursing to understand the following research question: "What are the socio-cultural, religious, and spiritual aspects presented in the experience of sickening people with colorectal cancer who experienced ostomy surgical treatment?"

\section{OBJECTIVES}

To interpret the socio-cultural, religious, and spiritual aspects of the experience of people getting sick from colorectal cancer submitted to surgical treatment with ostomy.

\section{METHODS}

\section{Ethical Aspects}

This study followed the Resolution no 510, of April 7th, 2016, about the norms of research in Human and Social Sciences, being approved by the Committees of Ethics in Research of the proposing and co-participating institutions, for being performed with specificity in a hospital scenario. The signing of the Free and Informed Consent (TCLE) occurred after the project's joint reading with the deponents. Sequential alphanumeric coding identified each patient (P1 to P11) and caregivers ( $C 1$ to $C 7$ ) to preserve their anonymity.

\section{Type of study and theoretical-methodological framework}

This study addresses ethnographic research, with a comprehensive sociological perspective ${ }^{(6)}$ and a methodological-conceptual strategy of short narratives, excerpt from the dissertation "The senses of colorectal cancer illness: an ethnographic study". The construction of short narratives in Health Sociology make available the sequential ordering of socio-cultural events (in this study, the CRC disease); analysis of data and reports respecting the individuality of the experience in order to avoid ethnocentrism; and incentive for orderly reports on the scenarios of actions and feelings that permeate the experience ${ }^{(5)}$.

Since the study's construction object, the data went from common sense to the sociological sense. Therefore, the daily language is moderated because at the same time that it expresses values, beliefs, and behaviors, it has a descriptive barrier that does not encompass the discovery of the new; there is no need for a "spontaneous sociology" that only reflects the trivial, but one sociology that makes it possible to interpret facts. The researcher becomes aware and delimits the field of his ethnographic study, trying to describe his apprehensions. Nevertheless, at each contact, there is a new look at reality, a view of how individuals act, their motives of actions, regardless of what is evident ${ }^{(13)}$. 


\section{Methodological procedures}

\section{Study setting}

The patient search for participants took place at a High Complexity Oncology Care Center, in the metropolitan region of a city in Pará, Brazil. The study's context was on an oncologic surgical center with 18 wards, totaling 22 beds. The contacts were made preoperative and postoperative after each participant's return from the Intensive Care Unit (ICU). The fieldwork for data collection took place from September 2018 to March 2019, and the total time of connection with each of the participants ranged from 7 to 33 days.

\section{Data source}

Sociological sampling reproduced the environment, context, and significant interactions for the object ${ }^{(6)}$. Therefore, it was considered the patient-caretaker binomial due to the difficulty in conducting interviews only with primary participants (patient), with the need of secondary participants (caregivers) accompanying the therapeutic itinerary and hospitalization. The selection criteria of the participants for this study were: patients with colorectal cancer under surgical treatment, residents in the city, over 18 years old, with no reports of psycho-emotional exhaustion and with intestinal ostomy. Eighteen deponents appeared in data sources: seven caregivers $(C)$ and eleven patients $(P)$.

\section{Collection and organization of data}

The study respected the Consolidated Criteria for Reporting Qualitative Research (COREQ) ${ }^{(14)}$ items in the domains of "research team and reflectiveness", "study design", "analysis", and "findings".

In fieldwork, the techniques employed were non-participating and participant observation, through the insertion of the researcher in the context and approximation since the preoperative admission in the surgical unit to the participants, with the use of empathic listening, a dialogue of clarification about the study, and informal conversations about the care and expectations after hospital discharge. In the non-participating observation were considered dynamics, organization, the service's routine, and procedures. On the other hand, the participant observation took place according to sociological assumptions of hearing and interaction ${ }^{(13)}$ : one asked about the experience of being hospitalized, listening to the itineraries, life habits, and opinions regarding the care. The usage of field diary happened all the time as an instrument for data recording.

The ethnographic notes in the diary respected date and list of subjects, events observed in keywords, narratives, feelings, reflections, first interpretations, and notes for the next meeting. The semi-structured interview held in the wards during the postoperative period included the following questions: "What could you tell me about your health problem?"; "What do you think caused this problem?"; "What matters for you now?"; "What are your plans for the future?"; "Do you think your life will change after the surgery? In what way?"; The length of the interviews varied from 15 to 36 minutes.

Subsequently, the sociological strategy of relevance was performed through triangulation with ethnographic notes, reflections of the researcher, and post-operative interviews, generating a Microsoft Word ${ }^{\circ}$ file for each patient or binomial when necessary. After the familiarization with the concrete data characteristics, the individual interviews were arranged in a single matrix file to analyze similarities and identify data novelty.

\section{Data analysis}

The data management, categorization, and legitimization were performed by the team, with no software use. After organizing the master file, they treated the material in light of the analysis of inductive content in six stages: 1) Familiarization - transcription, reading, and rereading to explore the critical points of the speech, with a request for further clarification as the contacts intensified; 2) Systematic codification of concrete data characteristics; 3) Generation of units by thematic proximity between the senses; 4) Analysis of connections between the units; 5) Generation of names for the units and senses; 6 ) Report ${ }^{(15)}$. According to the Durkheimian conceptual inspiration on the research object, the concreteness of socio-cultural, religious, and spiritual facts was used from particularities of analysis to the definition of unity of meaning. These Social Facts, for the sociologist, are the elements originating from a conceptual model of collective thought or behavior and external coercion in the individual sphere, with the fixation of public consciousness ${ }^{(7)}$; they are reflected in the statements and identified primarily in the field diary and validated by the research team in the matrix file.

\section{RESULTS}

Eighteen deponents participated, including eleven patients, four men and seven women, all linked to the Unified Health System (SUS) as the only health care provider. They came mostly from cities in the countryside of Pará, except for one participant from Piauí and another from Maranhão, but they were living in the city during the period of data collection. The monthly income of two primary participants was less than one minimum wage, seven with one minimum wage, one with two minimum wages, and one participant with three minimum wages (reference for the periods: 01/01/2018 - R\$ 954.00 and 01/01/2019- $R \$ 998.00$ ).

Six patients were between 30 and 59 years of age, and five were 59 years of age or older. Regarding education: one participant had no formal education; five did not complete elementary school; three completed elementary school; one had not completed high school, and one completed high school. The seven secondary participants were all female: four wives, one daughter-in-law, one daughter, and a friend of the patient; three aged from 18 to 40 , two aged from 40 to 59, and two were over 59. The deepening of the interpretation is in the unity of meaning, Future perspectives, feelings, and sociocultural-religious behaviors, with three senses presented as follows.

\section{The Immediate Dream and Future Prospects}

The oncologic disease threatened the conscious or unconscious dreams from restoring their lives, especially concerning work and family maintenance, as well as socially constructed trends and feelings. 
Get well! (P9) [Field diary P9: On her first day of hospitalization, she was lying down without verbalizing much. She cried a lot when during admittance, thinking that she would not leave the institution alive]

I will ignore my thought [takes hands to face]. I just want to get well, to continue thinking like lused to do [what was your thought?] It was to work, those stupid little things, to build a fence, grow an orchard, weed my yard. If they do not want me to, I will not do it [family]; I just want to have some life for a while. (P5) [Field diary P5: likes to eat any fish, grows an orchard and admires an acai palm plantation near the mangrove as a hobby; Field diary: acai berry, the Euterpe oleracea, provides a typical fruit from Pará used in different ways]

The Immediate Dream is the expectation about physical recovery and hospital discharge, with health valuation to be happy again, with hopes to make new dreams come true.

My definitive healing, to leave here healed in the name of Jesus. In my nutrition, I will be a new woman; I will apply the nutrition habits learned here. (P6) [Field diary P6: likes to eat barbecue and walk in the mall as a hobby]

I wanted everything to work out [three P7 reorders], that we could get out of here. I know there are many things ahead, and this ostomy pouch will not have much importance. (C3)

The doctor explained, despite the advance of the disease, she wants to return home. (C4) [Field Diary P8: she likes to eat fish and as a hobby like visiting her friends]

Attached to the Immediate Dream, the family becomes a coparticipant in future plans:

We do not have plans at the moment. Our children are planning trips when he is well. I have another son who is planning to arrange someone [to help] because we live alone. So, they are full of plans, we are full of hope, and from now on, we will change our life. (C1)

Back to my normal self, what I did before, I like to work. Help to raise my granddaughter, reform my workshop [...] she will turn 4 , on 11, and every day she sends audios asking how I am. (P1) [Field diary P1 - reconstruction of intestinal traffic: he likes to eat fish and game meat, drives as a hobby]

My plan is to get my life back. I used to like the work, but not now, I already admit that it can't be like this anymore [...]. (P3) [Field diary P3: likes to eat country chicken with jambu leaves; Field diary: Acmella oleracea, typical Amazonian plant used in cooking, causing tingling and numbness in lips and tongue when consumed]

It's only a year before my daughter graduates from social work, and I want to be healthy enough to be there with my grandchildren; she didn't finish this year because she said: "No mother, now it's your turn!" [start crying, and I ask her if she wants to finish the interview]. No, no, I like to cry. My focus now is to be healthy and do everything right because next year, God willing, my daughter will go, and I will stay with my grandson. My life's purpose. (P4) [Field Diary P4: likes simple food; make crochet and crafts as hobbies]

\section{Socio-religious and spiritual behaviors}

Awakening to God was a social fact or religious experience after a life self-declared as disinterested in health. It occurred in the hospital due to the uncertainties of (con)living with the collecting bag and the chapel's use as a prayer space by Catholics.

Thank God, I got rid of my drinking addiction. When I got sick, I said "It's time to change", I woke up, because we are human beings. We have the opportunity of life and the awakening, now if you don't want to [...]. It's the law of survival. Have you thought about using it for two years? [points to colostomy] Only with a miracle, He knows us from the womb. (P1) [Field diary P1: reconstruction of intestinal transit; Foursquare Church Protestant]

I was always asking to restore my health, two days before surgery a team of doctors came in and said that I would stay a while with the pouch and afterwards without the pouch. I was amazed, I knelt here, I became stronger, because when we trust, He answers. The right moment, it's His time, not yours, I don't have words to thank. (P6) [Field diary P6: rosary on the wrist and wearing a scapular; Catholic]

I pray using my rosaries, I like to cry because that's when seek strength from God, it seems like I am staying in His lap crying. I breathe and I get strength and I feel good. If God and Our Lady wants to, I will be better! (synthesis P4 and P5) [Field diary: Catholics]

Before surgery, we prayed the rosary in the chapel, on Thursdays, the celebration of word. She came to the clinic with her and we stayed in the chapel. (C7) [Diary C7: nuns, 60 years of religious life of P11]

There was a combination of sacred elements in the hospital setting, such as rosaries in the serum supports, and in the oxygen flowing tubing in the infirmaries, and Bibles next to the pillows. There was an attribution as angels or instruments of God to the professional's figure or someone "known".

When he was first seen by the physician [outpatient], sincerely I thought it is God's doing [...]. The doctor wrote in his chart "surgery with urgency"; because of these words, it was faster, so I say it was God's instrument [teary eyes]. Without that urgency, I would only have that surgery after six months, said the social worker [...]. They called after 20 days for admission. (C1)

[Field diary P11: She was babbling incomprehensibly and your caregiver explains to me].

She was mentioning that when she was waiting for an ICU bed, a doctor making the rounds entered her room and recognized her because he had studied at the school where she lived. He helped her with her agility. It is in our Lord's hand, the doctors are helped by God, and nobody does anything by themselves [...] she wanted the surgery. (C7)

We ran out of money, and He sent this angel [Field diary P5: about the "girl" in the hospital who speeded up the hospitalization] to help us and who brought us here. (P5) 


\section{Behavioral etiologies that trigger colorectal cancer, knowl- edge, and traditional forms of treatment}

The food status was linked to the low ingestion of greens and vegetables at meals and the traditional lunch of acai berry mush (Field Diary: typical dish prepared with fruits from the acai palm Euterpe oleracea), with manioc flour (Manihot esculenta). The conditions of socioeconomic status, employment, and heredity made up the lexicon of eating habits.

Dried food, did not like greens and vegetables, be sure was it is! He ate beans, meat or chicken, rice, and flour. In our childhood, we were poor, just eating acai berry with flour. (P6)

He worked in a mining, had no fresh water, and only ate game. (C3)

It has a heredity, a family history. (synthesis C1, C6 and C7)

He smoked a lot foryears, but smoking damages the lung and not the rectum [...]. [Field diary: P3 smoked for over 20 years. After explaining the risk factors and diet, the caregiver remembered some of her husband's habits] [...] I fried steak with beans and rice. He took the oil from the steak with the spices and threw it in the meal. "My God, don't do that, man! It's bad for you!" He'd say, "This is the tasty part, woman! With a lot of oil." Who knows if that was not the cause of all this? (C2)

The remosa food, is a term used to describe a food taboo in Northern of Brazil. It is mentioned because of its potential to damage tissues and (generate) infections. Popular wisdom strongly contraindicated this kind of food in the postoperative period.

I associate it with a pig I ate. [Field diary: when asked about the reason for this association, she referred to a remosa food]. Since the problem was in the rectum, it covered the passage, stufted, and closed. (P4)

She went to my home for lunch and ate some mayonnaise; it took ten minutes, and she said it would do her harm. She felt a stomachache; I gave her a brandy, so she could get home. Since then, she is just decaying, losing weight quickly, and saying she had never been well after that mayonnaise. The female physician who diagnosed her said that it had been three years acting inside her, slowly! [Field diary: What is the reason for the report on a homemade mayonnaise?]. It is because the egg is remoso. (C4)

In the popular system it is common self-medication by using "German brandy", a tincture known as "Jalapa" (Field Diary: jalapas are climbing plants of the Apocynaceae and Convolvulaceae families, and their tubers have laxative potential), It is used with the aromatic plant Arruda (Field Diary: Ruta graveolens, a medicinal plant) mixed with sugar. With similar apprehension to the pill, which is a cultural trait of traditional medicine linked to the biomedical knowledge system.

It was more a homemade medicine. I almost didn't get sick; when my stomach was swallowed, I drank boldo tea. [Field diary: Peumus boldus, considered a medicinal plant for gastrointestinal problems]. The strongest illness I had was the flu, and I took some pills [...]. And that was it. But now I have pain night and day, and
I'm going to the bathroom all the time, and the pain, I cried a lot while I'm in the bathroom. (P5)

A warning testimony about $\mathrm{CRC}$, a social phenomenon derived from adversities, recommended looking for signs of sickness.

I only went to the bathroom every three or four days. I thought it was expected, I never saw a comment on television, in a newspaper otherwise. Today I say, "People, if you are like I was, you must go, go!" At the moment it was shown in some program, I got lost // was stupefied. It didn't hurt, it didn't bleed. "Boy, am I normal," and in that thesis, I stayed. When I have the opportunity, I give my statement to the people who will visit me, I want to be an alert for people. Not to be like I was, nobody guided me or warned me. Was it a lack of opportunity? I don't know what it was. I thought it was normal. (P4)

The allusion to the Immediate Dream and the family conditioned the future, and the hospital constituted a place for divine supplications, defining the interpreted aspects. There is a linkage of cancer onset to socioeconomic status, poor diet, and heredity; about social medicalization, there is a coexistence of popular and biomedical archetypes.

\section{DISCUSSION}

The apprehension of Immediate Dream, spiritual social-religious behaviors, and the food taboo of remosity are highlighted as strong constituents of this study. The participants' self-identity, acquired and assimilated, changed. From now on, changes will be processed in social roles, habits, and expectations, derived from the vast socio-cultural institutions. These individuals will suffer new meanings that transcend the immediate dimension, the disease itself ${ }^{(16)}$, and, to adapt, they count on situational resignification, attachment to religion or spirituality, and reflection about habits.

The first sense learned is that working or remaining useful through domestic activities indicates the social importance of labor in self-realization, personal dignity, financial independence, and sociability for the human being. Community and family entertainment activities or resuming studies support the new lifestyle after ostomy ${ }^{(17-18)}$. The Immediate Dream is the interruption of dreams embedded in the social environment, consequent to the disease verified by the established diagnosis, mourning for the lost identity, wondering if there is a way to take care of the family, and how the stoma will damage someone's life ${ }^{(19)}$.

Emotional shock links to an intense psycho-emotional burden affecting the future, which in this study was the treatment with ostomy. The critical illness (CRC) attacks the physical progressively: sedation, the technological density of the surgical treatment, functional impairment, unconsciousness, recovery, and concerns with healing generates a sensation of losing control of the circumstances, with psycho-emotional repercussions that interrupt the dreams ${ }^{(1)}$.

The second sense corroborates that religiosity and spirituality strengthen the participants, and beliefs modify the itinerary; faith articulated the illness experience's reflexive construction. There is a lack of professional approach on the subject, reflecting a biomedical-functional practice ${ }^{(20-22)}$. 
The totality professed Christian religions linking God to redemption and connecting with Him through prayers, gospel reading, kneeling, and crying, denoted by the interpositions of the sacred in the physical hospital space. These experiences of the sacred and the divine indicate the search for acceptance of the consequences of ostomy, through the intermediation of an omnipresent and omniscient Being who provides uninterrupted protection. Rosaries in the serum holders, in the oxygen flow tubing and Bibles beside the pillows denote modern totemism, consisting of multiple forms of worshiping God, a heterogeneous phenomenon of recognition of the participants' connection with the divine and the importance of magical-religious, symbolic and ritualistic practices ${ }^{(23)}$.

The participants' gratefulness for diagnosis and/or hospitalization at the right moment, and the professionals' denomination who helped them acting as "instrument of God" or "angels" configure the symbolism of professional institutionalization for specialties in Brazilian society, which subsidize the credibility of the biomedical system in the High Complexity Oncology Care Center ${ }^{(24-25)}$. Thus, the sovereign authority is attributed to physicians as decision-makers over the lives of the patients ${ }^{(25)}$.

Valuable discoveries were synthesized in the elaboration of the third sense. There was the claim of common sense about the "dry" diet, poor in fruits and vegetables, exclusive preference for Euterpe oleracea extract, rice, beans, and meat as the cause of CRC disease, converging with the scientific literature on risk factors, mainly regarding the positive association of low intake of grains, fruits, vegetables and high consumption of red meat, fat meals and sugar with colorectal cancer ${ }^{(26-27)}$. For this, establishing a "chemopreventive" strategy is recommended with the consumption of olive oil, red wine, and tomatoes ${ }^{(28)}$, even though this represents a distant food reality for the patients in Amazon.

Poverty, more affordable prices, and labor insalubrity were part of the narratives without the need for theoretical-analytical interference, and the participants are responsible for reflecting on their illness experience in the biomedical context ${ }^{(29)}$. Such action was verified in the speech of $\mathrm{P} 2$, indicating that the ingestion of oil portions by the husband started to make the couple reflect about the (de)construction on eating habits. Therefore, the individual's indiscriminate use to explain illness is incomplete. The habitus as an explanatory source of health problems in terms of lifestyle involves the processes of socialization and structuring of eating habits, cumulative effects, plus social and political-economic determinants that also limit accessibility to healthy consumer goods ${ }^{(26,28,30)}$.

Therefore, it is recommended for Health Promotion to extrapolate individual determinism as the only source of analysis and assist the patients in the historical-social (de)construction on life habits, with realistic adoption of healthier behaviors and healthier foods to prevent $\mathrm{CRC}^{(30-31)}$. In this sense, one should consider the slowness of such a process, as reported by a NorthAmerican study that reported increased consumption of fruits and vegetables only after overcoming adverse events in therapies ${ }^{(32)}$. Consequently, the most accessible negative experience at the time of hospital admission would result in a social performance alert viewed as redeeming.

Food reimosity (or remosity) was reported, evidencing strong cultural and ritualistic tendencies about this popular designation in the Northern Region of Brazil, debated as a food taboo: "[...] means the flow of a liquid or the flow of organic humor, while remosity is all that causes reima"(33). The classic ethnographic work of Maués and Maués ${ }^{(34)}$ analyzed food taboos in an Amazonian rural-extractive community, where this term indicated harmful or poisonous potential if consumed by people in poor health. Pork, duck, turkey, crab, shrimp, fish without scales or golden and black colors, game animals, and animal origin foods such as eggs would be reimosed.

In the dialogue between biomedical and popular knowledge, it is emphasized that most of these animals feed on decomposing organic matter, but even though cooking time can destroy bacteria, does not eliminate toxins. This can activate the innate immunity, making healing difficult. Despite the lack of recognition by the biomedical system, some professionals in the Northern Region of Brazil recommend abstention from these foods after hospital discharge. People with a latent disease could have their condition aggravated by their ingestion, as reported by two deponents (P4 and C4, from the cities of Belém and São Luís, respectively) - it would be an intensifying element in the symptoms of cancer; however, the literature on this food taboo is scarce, and its pathophysiological mechanisms are unknown ${ }^{(33)}$.

In the fight against symptoms, the common sense recommends "pills" ("jalapa tincture") as herbal medicine found in popular pharmacies (Field Diary: contraindicated for tumoral disease) and the infusion/juice of common rue (Field Diary: Ruta graveolens, a medicinal plant with anti-inflammatory action) with sugar. Medicalization alludes to medical intervention in society, based on the assumption that the disease needs remedies and university and laboratory knowledge also dominate non-clinical systems. Despite recognizing medicalization as essentially from the university-scientific environment, the "medical knowledge" of other ritualistic and traditional aspects strengthens medical social control. The different adaptive medicalizations and with non-medical operators occur with the acceptance, prestige, and social control of their executors of common sense or biomedical sphere; thus, the biomedical aspect still has hegemony with complete acceptance for its achieved social status ${ }^{(24)}$.

The ethnographic studies focused on oncologic hospital care differ from those community-based by contributing to the immersion and understanding of the organizational culture in this health care context, to improve the approach to users and establish connections. On account of contact limitations with the patient in the hospital environment because of the workload, professionals adopted functional biomedical thinking. However, understanding knowledge, lifestyles, food preferences, and emotions with the depth of ethnography broadens the understanding of humanization and improving the quality of care in the public health system ${ }^{(35)}$.

\section{Study limitations}

The findings such as behaviors, feelings, and ideals are proper for patients living CRC in a surgical clinic, interfering in the narrated experiences. Besides, short-term ostomy experience was a limitation because the socio-cultural, religious, and spiritual aspects were not sufficiently experienced outside the hospital 
environment and resuming daily routine, which could have amplified the results.

\section{Contributions to the fields of Nursing and Health}

The interpretation reached by sociology made it possible to understand the experiences of people suffering from CRC in surgical treatment with ostomy, analyzing the influences of microsocial and macrosocial factors, essential for the public health policies of the SUS in terms of humanization, from the itinerary to hospitalization for ostomy. Such aspects need to be considered in planning the interprofessional assistance of these users, expanding the functionalist biomedical perspective.

\section{FINAL CONSIDERATIONS}

The socio-cultural, religious, and spiritual factors of patients' experience by CRC in treatment with ostomy were linked to the expectation of the Immediate Dream in hopes of resuming of life, maintenance of a food taboo of the North Amazon Region (the reimosity of food/ toxic food remosity), habits of life and religious spirituality. It is impossible to dissociate these narrative experiences, before and after surgical treatment, from the reflection on perioperative care and implementation of public policies of oncologic attention in the SUS, as well as strategies, to confront these users during hospitalization in the North Amazon Region.
The analytical construction of the social fact of the Immediate Dream of hospital discharge is significant; first of all, by the waiting for recovery, confused or not with healing, flowing into urgent dreams, justified by the aspiration of return to work and the resumption of life with and despite ostomy. In the waiting for the surgery, the sick thought about God's plans, with proximity to sacred objects (attachment figures) and modern totemism in the clinical hospital space, conferring, therefore, strength in the perioperative.

In complex societies, in urban centers, there is a coexistence of traditional and modern perspectives, indicating strong ideological relations between macrosocial and microsocial, making the sociological construct on health care indispensable, through the listening of narratives of the sick about the disease and their interaction with the professional-biomedical system.

\section{FUNDING}

Research supported by the Coordination for the Improvement of Higher Education Personnel (CAPES); Master's degree researcher's grant code: 4892065 .

\section{ACKNOWLEDGEMENT}

Acknowledgments for the assistance of the High Complexity Oncology Care Center team.

\section{REFERENCES}

1. Tembo AC. Critical illness as a biographical disruption. Singapore Med J. 2017;26(4):253-9. doi: 10.1177/2010105817699843

2. Instituto Nacional de Câncer José Alencar Gomes da Silva, INCA (Brasil). Estimativa 2020: incidência de câncer no Brasil [Internet]. Rio de Janeiro: INCA, 2019 [cited 2020 Jan 08]. Available from: https://www.inca.gov.br/sites/ufu.sti.inca.local/files//media/document//estimativa2020-incidencia-de-cancer-no-brasil.pdf

3. Beets G, Sebag-Montefiore D, Andritsch E, Arnold D, Beishon M, Crul M, et al. ECCO essential requirements for quality cancer care: colorectal cancer. a critical review. Crit Rev Oncol Hematol. 2017;110:81-93. doi: 10.1016/j.critrevonc.2016.12.001

4. Vonk-Klaassen SM, Vocht HM, Ouden MEM, Eddes EH, Schuurmans MJ. Ostomy-related problems and their impact on quality of life of colorectal cancer ostomates: a systematic review. Qual Life Res. 2016;25(1):125-33. doi: 10.1007/s11136-015-1050-3

5. Castellanos MEP. The narrative in qualitative research in health. Ciênc Saúde Colet. 2014;19(4):1065-76. doi: 10.1590/1413-81232014194.12052013

6. Gold RL. The ethnographic method in sociology. Qual Inq. 1997;3(4):388-402. doi: 10.1177/107780049700300402

7. Durkheim E. As regras do método sociológico. São Paulo: Edipro, 2012.

8. Nunes ED. A construção teórica na sociologia da saúde: uma reflexão sobre a sua trajetória. Ciênc Saúde Colet. 2014;19(4):1007-18. doi: 10.1590/1413-81232014194.12422013

9. Guimarães AN, Schneider JF, Camatta MW, Nasi C, Ferraz L, Pinho LB. Internação psiquiátrica no hospital geral de alcoolistas do meio rural: expectativas dos familiares. Rev Bras Enferm. 2019 Dec; 72(6):1442-9. doi: 10.1590/0034-7167-2017-0710

10. Siman AG, Braga LM, Amaro MOF, Brito MJM. Desafios da prática na segurança do paciente. Rev Bras Enferm. 2019;72(6):1504-11. doi: 10.1590/0034-7167-2018-0441

11. Rodrigues TFCS, Sanches RCN, OMLF, Pinho LB, Radovanovic CAT. Sentimentos de famílias na dependência de drogas: à luz da sociologia compreensiva. Rev Bras Enferm. 2018;71(Suppl 5):2272-9. doi: 10.1590/0034-7167-2018-0150

12. Rozmovits L, Ziebland S. Expressions of loss of adulthood in the narratives of people with colorectal cancer. Qual Health Res. 2004;14(2):187203. doi: $10.1177 / 1049732303260874$

13. Paugam S. A pesquisa sociológica. Petrópolis, RJ: Vozes, 2015.

14. Tong A, Sainsbury P, Craig J. Consolidated criteria for reporting qualitative research (COREQ): a 32-item checklist for interviews and focus groups. Int J Qual Health Care. 2007;19(6):349-57. doi: 10.1093/intqhc/mzm042 
15. Braun V, Clarke V. Using thematic analysis in psychology. Qual Res Psychol. 2006;3(2):77-101. doi: 10.1191/1478088706qp063oa

16. Berger PL, Berger B. Socialização: como ser um membro da sociedade. In: Foracchi MM, Martins JS. Sociologia e sociedade: leituras de introdução a sociologia. Rio de Janeiro: LTC, 2018. p. 169-181.

17. Neves DR, Nascimento RP, Felix Jr MS, Silva FA, Andrade ROB. Sentido e significado do trabalho: uma análise dos artigos publicados em periódicos associados à Scientific Periodicals Electronic Library. Cad EBAPE.BR [Internet]. 2018 [cited 2019 Jun 03];16(2):318-30. doi: 10.1590/1679-395159388

18. Boehs STM, Silva N. Papel de trabalho, carreira, satisfação de vida e ajuste na aposentadoria. Rev Bras Orientac Prof [Internet]. 2017 [cited 2019 Jun 01];18(2):141-53. doi: 10.26707/1984-7270/2017v18n2p141

19. Salamonsen A, Kiil MA, Kristoffersen AE, Stub T, Berntsen GR. "My cancer is not my deepest concern": life course disruption influencing patient pathways and health care needs among persons living with colorectal cancer. Patient Prefer Adherence. 2016;10:1591-600. doi: 10.2147/PPA.S108422

20. Kimura CA, Kamada I, Guilhem DB, Modesto KR, Abreu BSD. Perceptions of ostomized persons due to colorectal cancer on their quality of life. J Coloproctol. 2017;37(1):1-7. doi: 10.1016/j.jcol.2016.05.007

21. Reis CGC, Farias CP, Quintana AM. Emptiness of sense: religiosity support for patients with advanced cancer. Psicol Ciênc Prof. 2017;37(1):106-18. doi: 10.1590/1982-3703000072015

22. Rohde G, Kersten C, Vistad I, Mesel T. Spiritual well-being in patients with metastatic colorectal cancer receiving noncurative chemotherapy: a qualitative study. Cancer Nurs. 2017;40(3):209-16. doi: 10.1097/NCC.0000000000000385

23. Montero P. A teoria do simbólico de Durkheim e Lévi-Strauss: desdobramentos contemporâneos no estudo das religiões. Novos Estud CEBRAP. 2014;(98):125-42. doi: 10.1590/S0101-33002014000100007

24. Correia T. Revisiting medicalization: a critique of the assumptions of what counts as medical knowledge. Front Sociol. 2017;2:14. doi: 10.3389/fsoc.2017.00014

25. Ribeiro ACL, Ferla AA. Como médicos tornaram-se deuses: reflexões acerca do poder médico na atualidade. Psicol Rev. 2016;22(2):294-314. doi: 10.5752/P.1678-9523.2016V22N2P294

26. Almeida L, Santos BT, Prates RP, Leão LL, Pereira ÉJ, Silva VS, Farias PKS. Alimentação como fator de risco para câncer de intestino em universitários. Rev Bras Promoç Saúde. 2017;30(1):72-8. doi: 10.5020/18061230.2017.p72

27. Mehta RS, Song M, Nishihara R, Drew DA, Wu K, Qian ZR, et al. Dietary patterns and risk of colorectal cancer: analysis by tumor location and molecular subtypes. Gastroenterology. 2017;152(8):1944-53, 2017. doi: 10.1053/j.gastro.2017.02.015

28. Farinetti A, Zurlo V, Manenti A, Coppi F, Mattioli AV. Mediterranean diet and colorectal cancer: A systematic review. Nutrition. 2017;43:83-8. doi: 10.1016/j.nut.2017.06.008

29. Pacheco RA, Onocko-Campos R. “Experiência-narrativa” como sintagma de núcleo vazio: contribuições para o debate metodológico na Saúde Coletiva. Physis [Internet]. 2018;28(2):e280212. doi: 10.1590/s0103-73312018280212

30. Madeira FB, Filgueira DA, Bosi MLM, Nogueira JAD. Lifestyle, habitus, and health promotion: some approaches. Saúde Soc. 2018;27(1):10615. doi: 10.1590/s0104-12902018170520

31. Klotz-Silva J, Prado SD, Seixas CM. The power of "food habit": conceptual references to the field of Food and Nutrition. Physis [Internet]. 2017;27(4):1065-85. doi: 10.1590/s0103-73312017000400011

32. Shaffer KM, Kim Y, Llabre MM, Carver CS. Dyadic associations between cancer-related stress and fruit and vegetable consumption among colorectal cancer patients and their family caregivers. J Behav Med. 2016;39(1):75-84. doi: 10.1007/s10865-015-9665-y

33. Brito Jr LC, Estácio AG. Tabus alimentares em medicina: uma hipótese para fisiopatologia referente aos alimentos remosos. AMB Rev Assoc Med Bras. 2013;59(3):213-6. doi: 10.1016/j.ramb.2013.04.001

34. Maués HR, Maués AG. O modelo da "Reima": representações alimentares em uma comunidade amazônica. An Antropol [Internet]. 1978 [cited 2019 Feb 22];2(1):120-47. Available from: http://periodicos.unb.br/index.php/anuarioantropologico/article/view/6016

35. Vougioukalou S, Boaz A, Gager M, Locock L. The contribution of ethnography to the evaluation of quality improvement in hospital settings: reflections on observing co-design in intensive care units and lung cancer pathways in the UK. Anthropol Med. 2019;26(1):18-32. doi: $10.1080 / 13648470.2018 .1507104$ 